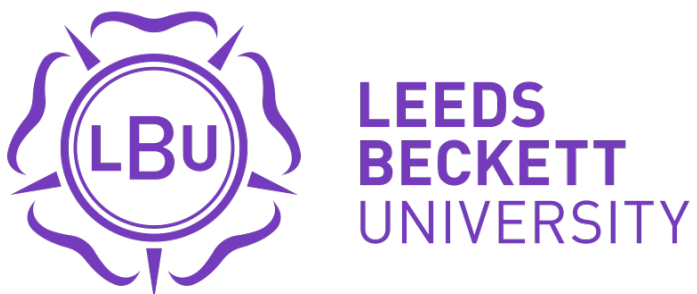

Citation:

Julian, R (2016) Unarmed Civilian Peacekeeping. Peacekeeping Challenges and the Responsibility to Protect (R2P).

Link to Leeds Beckett Repository record:

https://eprints.leedsbeckett.ac.uk/id/eprint/3607/

Document Version:

Article (Published Version)

The aim of the Leeds Beckett Repository is to provide open access to our research, as required by funder policies and permitted by publishers and copyright law.

The Leeds Beckett repository holds a wide range of publications, each of which has been checked for copyright and the relevant embargo period has been applied by the Research Services team.

We operate on a standard take-down policy. If you are the author or publisher of an output and you would like it removed from the repository, please contact us and we will investigate on a case-by-case basis.

Each thesis in the repository has been cleared where necessary by the author for third party copyright. If you would like a thesis to be removed from the repository or believe there is an issue with copyright, please contact us on openaccess@leedsbeckett.ac.uk and we will investigate on a case-by-case basis. 


\section{Unarmed Civilian Peacekeeping}

November 16, 2016 · by Rachel Julian · in Peacekeeping Challenges and the Responsibility to Protect (R2P). •

Unarmed civilian peacekeeping represents both a practical and compassionate response to suffering and violence and challenges the conventional view that peacekeeping can only be effective through military measures.

\section{What is unarmed civilian peacekeeping?}

Unarmed civilian peacekeeping, also referred to as unarmed civilian protection (UCP), fields trained civilians using unarmed and other nonviolent methods to; protect other civilians from violence, deter armed actors, support local efforts to build peace, and maintain human rights. It challenges the assumption that peacekeeping and civilian protection requires the military and the use of weapons. Over the past 35 years, across the world, unarmed civilian peacekeepers have saved lives and enabled communities to stay at home rather than be displaced, made peace and human rights work more possible, involved more people and taken place in a wider area. UCP includes living with, and in, communities affected by violence, which supports the re-establishment of relationships and communication across divided communities. UCP is a visible, well known and often international presence which deters threats of violence and engages with armed actors about the protection of civilians.

The term UCP describes a set of activities that civilians undertake including (but not limited to) accompaniment, presence, rumor control, community security meetings, securing safe passage and monitoring (see Schweitzer 2010).

\section{Why is it important?}

UCP is important because millions of people need protection from violence and human rights abuses across the world, and UCP provides an effective, less costly, way of protecting them. One core element of effectiveness is building good relationships, and Furnari has shown that relationships are considered a critical tool by all peacekeepers.

UCP challenges the assumption that peacekeeping must be carried out by military actors and is reliant on the use of force by demonstrating, in many contexts and over 35 years, that violence can be prevented and deterred by using nonviolence. We know that this work challenges a widespread assumption that violence will only yield to violence because it demonstrates that violence and threats of violence can be tackled by unarmed trained civilians. This doesn't mean that UCP will work everywhere. As with all peacekeeping, it works because the armed actors acknowledge the presence of the peacekeepers and, to a certain extent, care about the impact of their actions. Military peacekeeping faces the same challenge.

"UCP is separate to other actors because it does not bring humanitarian aid nor conflict resolution solutions. By maintaining the focus on violence, asking for help from unarmed civilian peacekeepers isn't related to getting housing or aid, but it is about focusing on security, safety and the creation of mechanisms which will prevent children being abducted, will prevent retaliation attacks by controlling rumors, will ensure community leaders talk to 


\section{How does UCP work?}

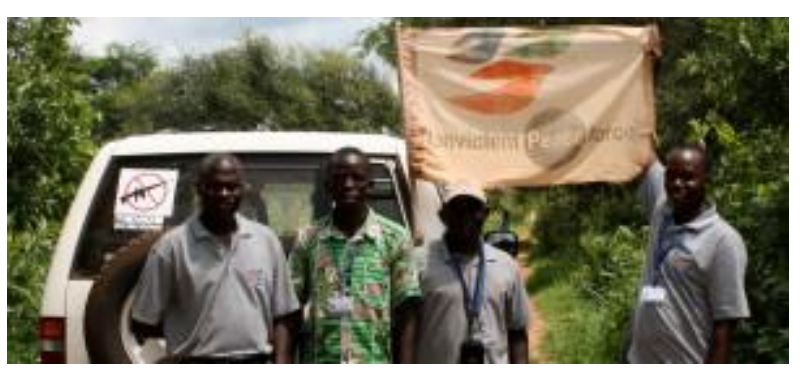

Image by Nonviolent Peaceforce/Flickr.

UCP is possible when the team members are very visible (a constant presence and observing is known to affect the way armed actors behave) and are known by, and know, everyone involved in the violence and conflict including civil society, businesses, armed actors, peace groups, mothers, youth groups, government, etc. The tools of an unarmed peacekeeper are being well known and their role being understood clearly, a phone so they are able to contact people should anything happen and be easily contacted, a camera to record events, a safe space people can visit, and resourcefulness to keep finding ways to prevent violence. Unarmed peacekeepers live and work with the people they are protecting (not in military barracks) which means they learn about existing community mechanisms and makes them accessible and able to provide a safe space in which new committees, training or meetings can take place.

There are three main theories explaining how UCP works.

- Firstly, the unarmed accompaniment by, and presence of, international peace teams deters armed actors from carrying out threats of violence. It is well known that observing armed actors deters them from carrying out violence and it has been used to protect human rights defenders in Colombia by Peace Brigades International (PBI) for 30 years, and none of the human rights defenders receiving protection have been killed, and they have been able to expand their work and support many more in understanding their human rights.

- The second approach is proactive presence where the unarmed civilians actively seek out the armed actors, and engage with them about their activities and the way they can reduce harm to civilians. This might involve dialogue, training on human rights, being able to contact commanders when early warning signs indicate violence is imminent. It has been used by Nonviolent Peaceforce in Mindanao and South Sudan.

- The final approach is relationship building. This is identified by Ellen Furnari as an approach that all peacekeepers (armed and unarmed) believe underpins the success of peacekeeping. By building stronger relationships between stakeholders it creates the web that can rebuild trust and peace communities.

All of these are used together and in every place where UCP is used around the world it is always context specific. It is adapted and developed by the people who work on the ground.

\section{How do we know it works?}


Over 35 years there have been team reports, evaluations, research and stories which show that the work and protective presence of unarmed, trained civilians have saved people's lives and prevented violence. For example in Mindanao the Nonviolent Peaceforce international protection team were a part of the official ceasefire monitoring process and have, in part, been credited with the success of the ceasefire lasting because the local community were very involved, good relationships were established and because the unarmed peacekeepers live in the affected communities, they are able to respond very quickly to violations and investigate incidents. In Guatemala, PBI created space for human rights defenders to work more widely with people because they could travel to remote areas. Accompaniment deters the violence but the work is led by the local people.

In South Sudan IDP's have been protected in their camps through the patrolling and interpositioning of unarmed civilian peacekeepers, including unarmed peacekeepers refusing to stand aside when threatened with a gun and saving women and children inside a tent. Women who we're being raped by soldiers were protected by accompanying the women as they collected water and the commanders of the soldiers were engaged.

In Sri Lanka in 2008 in Valaichennai violence was prevented from spreading when networks and re-established relationships meant that opposing groups refused to allow the other to be bombed in an emerging dispute. The Nonviolent Peaceforce UCP team had been Valaichennai for 5 years and built up relationships with a group of traders representing different conflict groups. In previous years, when violence flared up in a nearby town it had spread to Valaichennai. In previous events one group of traders shut their shops when they were warned about attacks on the others, meaning attacks on the other side didn't harm them. This time the traders agreed that if they were warned to shut their shops, all of them would remain open instead, and this action, combined with the presence of unarmed civilian peacekeepers on the street, the UCP team were able to ensure that rumours were controlled and leaders of the armed groups were kept informed about the action which stopped the violence spreading and threats issues to people and livelihoods.

\section{The growth of UCP in policy and practice}

As well as the local impact on individuals and communities UCP has been discussed in high level political and policy arenas. The High level panel report on Peace Operations includes the recognition that unarmed strategies must be considered. The UN Women Global report specifically includes the benefits of UCP, and the sub-committee on civil crisis management of the German Parliament held an expert hearing on UCP in 2016. UCP is now taught at UNITAR and at universities in the UK, Canada and the USA.

As the International Community (in its broadest sense) seek innovative solutions to address the ways in which conflict and violence are entwined with global challenges of poverty and climate change, UCP is creating an alternative paradigm for the ways in which we engage with armed actors and understand the cycle of violence, outside of the military. UCP has steadily grown over the past decades and there is now a research agenda and growing interest in policy, so it's use is expected to increase. For example the newly established international UCP Research Network links established and new researchers in this field and have their next face to face meeting in June 2017.

UCP is a form of peacekeeping which causes us to question our assumption that peacekeeping is a military activity. If we are serious about preventing violence and protection 
of civilians we need to have a range of tools available to us. UCP shows that armed actors are susceptible to the presence of trained unarmed civilians and will change their behaviour, that communities understand what protection is required and that we do not need the military and weapons in order to 'keep the peace'. UCP offers an approach which challenges the increasing focus on the need for 'robust' peacekeeping and shows that we do have alternatives.

\section{Further reading and information}

Wielding Nonviolence (2016) by Ellen Furnari (Editor). This book is collected research on case studies of South Sudan, Israel-Palestine, Colombia and Mindanao.

Organisations practicising UCP

There is a continuum of organisations, from an unarmed military, governmental organisation (OSCE) and civil society. The core innovation and development of UCP has taken place in civil society and here are nine main organisations whose work fits the two principles of nonviolence.This list is not exhaustive and does not include national and local projects. The full extent of UCP practice is not yet known, but anecdotal information indicates many communities create self-protection mechanisms.

$\underline{\text { Peace Brigades International }}$

$\underline{\text { Nonviolent Peaceforce }}$

$\underline{\text { Meta Peace Team }}$

$\underline{\text { Witness for Peace }}$

$\underline{\text { EAPPI }}$

Operation Dove

$\underline{\text { Fellowship of Reconciliation }}$

$\underline{\text { Swedish FoR }}$

$\underline{\text { Christian Peacemakers team }}$

Guatemala Accompaniment Project

Dr Rachel Julian has been working on UCP for 15 years with Nonviolent Peaceforce, as researcher, facilitator on the course by UNITAR and has presented on UCP internationally. She is Senior Lecturer in Peace Studies at Leeds Beckett University. 